\title{
Tensile Strength and Steam Oxidation Resistance of ODS FeCrAl Sheet and Tubes
}

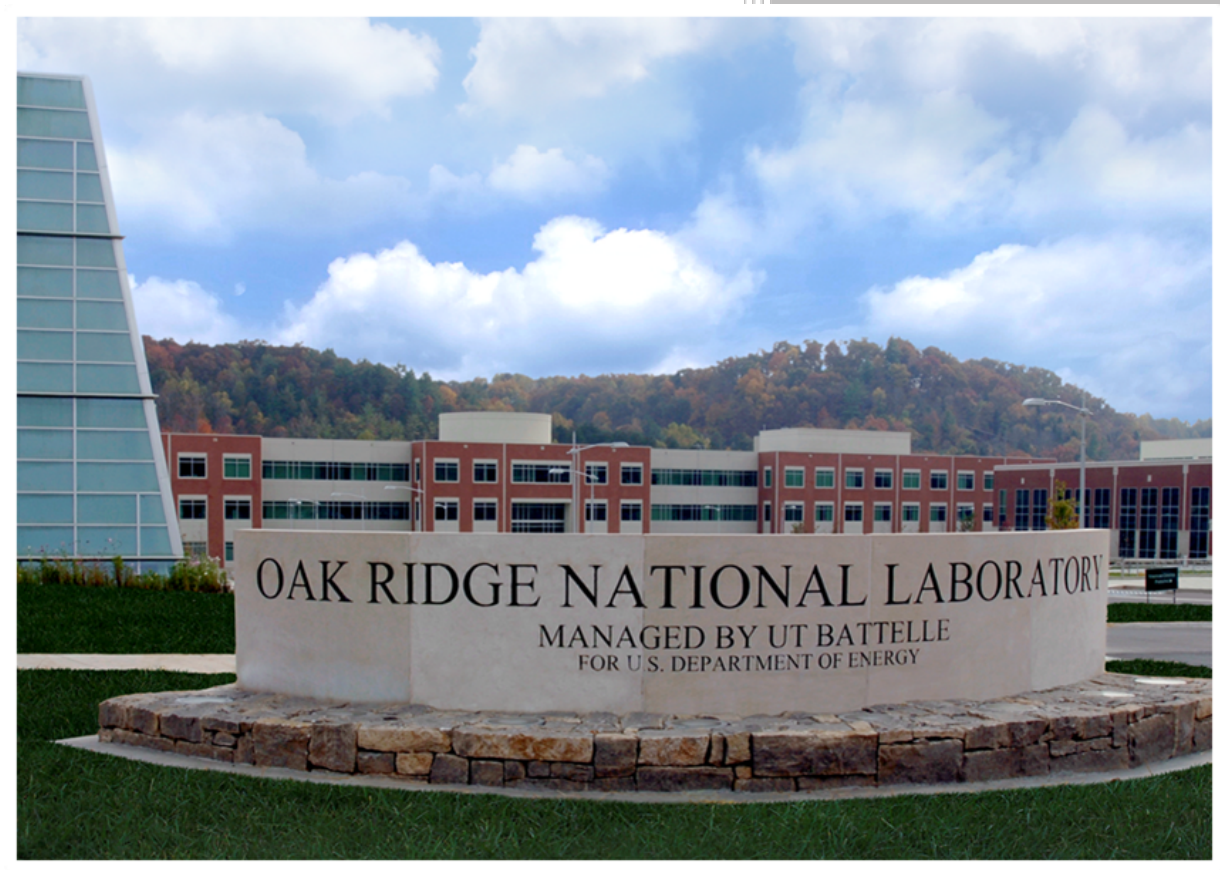

Sebastien Dryepondt Caleb P. Massey Maxim N. Gussev Kory D. Linton Kurt A. Terrani

May $30^{\text {th }}, 2018$

Approved for public release. Distribution is unlimited. 


\section{DOCUMENT AVAILABILITY}

Reports produced after January 1, 1996, are generally available free via US Department of Energy (DOE) SciTech Connect.

Website http://www.osti.gov/scitech/

Reports produced before January 1, 1996, may be purchased by members of the public from the following source:

National Technical Information Service

5285 Port Royal Road

Springfield, VA 22161

Telephone 703-605-6000 (1-800-553-6847)

TDD 703-487-4639

Fax 703-605-6900

E-mail info@ntis.gov

Website http://www.ntis.gov/help/ordermethods.aspx

Reports are available to DOE employees, DOE contractors, Energy Technology Data Exchange representatives, and International Nuclear Information System representatives from the following source:

Office of Scientific and Technical Information

PO Box 62

Oak Ridge, TN 37831

Telephone 865-576-8401

Fax 865-576-5728

E-mail reports@osti.gov

Website http://www.osti.gov/contact.html

This report was prepared as an account of work sponsored by an agency of the United States Government. Neither the United States Government nor any agency thereof, nor any of their employees, makes any warranty, express or implied, or assumes any legal liability or responsibility for the accuracy, completeness, or usefulness of any information, apparatus, product, or process disclosed, or represents that its use would not infringe privately owned rights. Reference herein to any specific commercial product, process, or service by trade name, trademark, manufacturer, or otherwise, does not necessarily constitute or imply its endorsement, recommendation, or favoring by the United States Government or any agency thereof. The views and opinions of authors expressed herein do not necessarily state or reflect those of the United States Government or any agency thereof. 
Fuel Cycle Research and Development, Advanced LWR Fuels

Tensile Strength and Steam Oxidation Resistance of ODS FeCrAl Sheet and Tubes

Sebastien Dryepondt, Caleb Massey, Maxim N. Gussev, Kory Linton and Kurt Terrani

Date Published: May $30^{\text {th }}, 2018$

Work Package Title: Improved ATF alloy: ferritic ODS development for fission platforms Work Package \#: NT-18OR02020205

Work Package Manager: Sebastien Dryepondt

Milestone \#: M3NT-18OR020202051

Prepared under the direction of the

U.S. Department of Energy

Office of Nuclear Energy

Fuel Cycle Research and Development

Advanced LWR Fuels

Prepared by

OAK RIDGE NATIONAL LABORATORY

Oak Ridge, TN 37831-6283

managed by

UT-BATTELLE, LLC

for the

US DEPARTMENT OF ENERGY

under contract DE-AC05-00OR22725 
This page intentionally left blank 


\section{CONTENTS}

\section{Page}

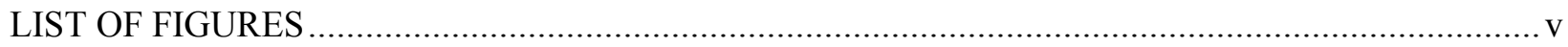

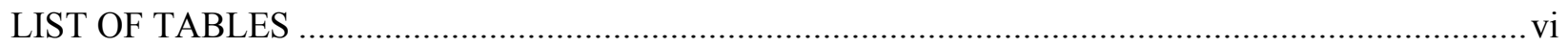

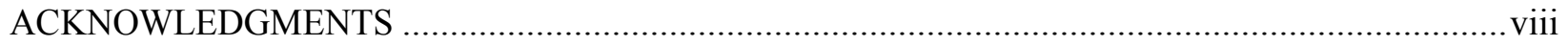

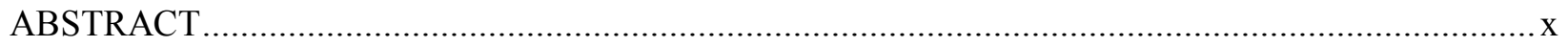

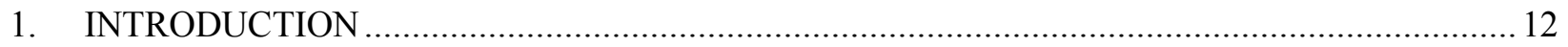

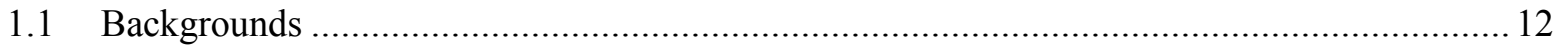

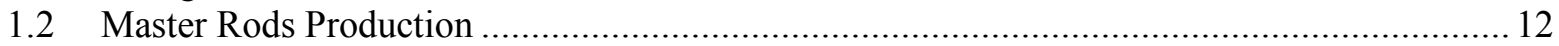

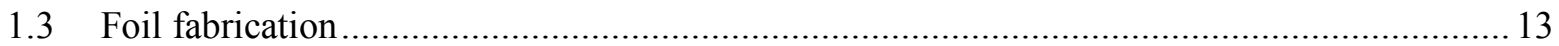

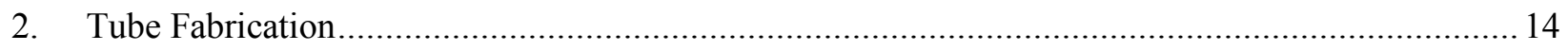

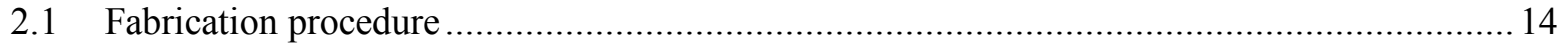

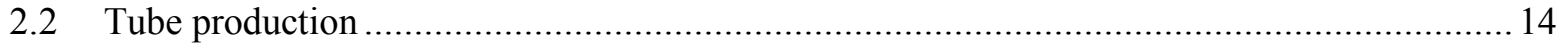

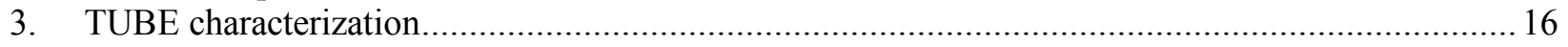

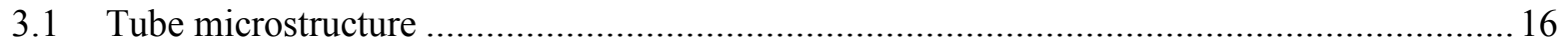

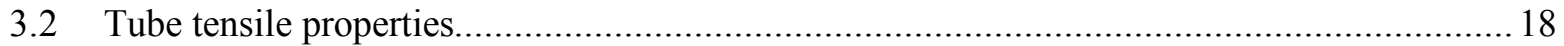

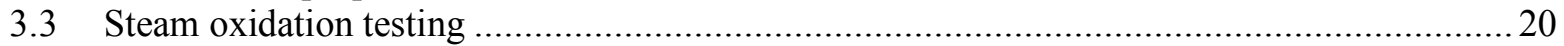

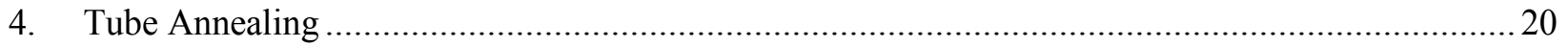

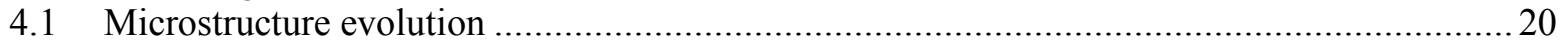

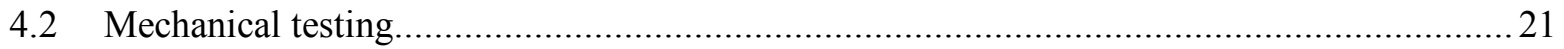

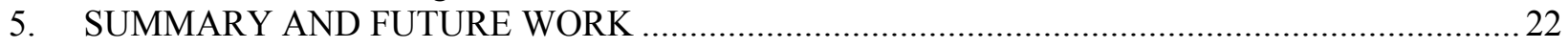

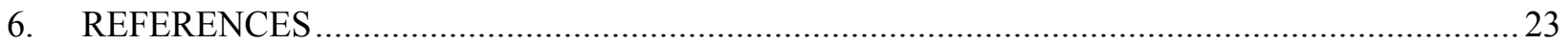


This page intentionally left blank 


\section{LIST OF FIGURES}

Figure

Figure 1: a) Extruded master rods, b) Evolution of the CrAZY alloy hardness with extrusion temperature....

Figure 2: a) Cold rolled foils, b) Evolution of the CrAZY foil hardness with foil thickness.

Figure 3. Examples of optical micrographs taken by the tube manufacturer to determine the optimum annealing temperature after each pilgering step....

Figure 4. a) Evolution of the tube hardness after each pilgering and annealing step compared to the hardness evolution during cold rolling of the foil, b) Picture showing the resulting 66 inch long tube

Figure 5. a) Tube cross-section, b) Wall thickness measurement

Figure 6. Cross-sectional back scattered scanning electron microscopy (BES-SEM) pictures of, a-b) the master rod, c-d) the cold rolled foil, and e-f) the tube.

Figure 7. EBSD grain map (left) and corresponding pole figure map (right) of the tube along the pilgering direction.

Figure 8. Three APT maps of the CrAZY tube showing the presence of (Y,Al,O) nano precipitates.

Figure 9. Schematic of the various specimens used to characterize the room temperature tensile properties of the master rod, foil and CrAZY tube.

Figure 10. Tensile curves at room temperature of the master rod, foil and CrAZY tube.....

Figure 11. Steam oxidation testing, a) experimental set up with CrAZY tube coupon ramped up to $1400^{\circ} \mathrm{C}, \mathrm{b}$ ) and c) oxide scale grown on the $\mathrm{CrAZY}$ tube after the $1400^{\circ} \mathrm{C}$ test.......

Figure 12. BSE-SEM micrographs of annealed materials, a) foil, $900^{\circ} \mathrm{C}$, b) $\mathrm{CrAZY}$ tube, $900^{\circ} \mathrm{C}$, c) foil, $\left.1100^{\circ} \mathrm{C}, \mathrm{d}\right) \mathrm{CrAZY}$ tube, $1100^{\circ} \mathrm{C}$

Figure 13. Curves comparing the tensile behavior of the foil and CrAZY tube before and after exposure for $1 \mathrm{~h}$ at $900^{\circ} \mathrm{C}$ 


\section{LIST OF TABLES}

Table

Table 1. Master rods composition measured by induction coupled plasma optical emission spectroscopy (most of the elements), combustion analysis (C and S), and inert gas fusion analysis $(\mathrm{O}$ and $\mathrm{N})$ 
This page intentionally left blank 


\section{ACKNOWLEDGMENTS}

The authors are grateful to Tyson Jordan, Greg Cox, Tracie Lowe and Michael Howell for their help with the experimental work. The authors want also to acknowledge Yuki Yamamoto and Stephen Raiman for reviewing this report.

This research was funded by the U.S. Department of Energy's Office of Nuclear Energy, Advanced Fuel Campaign of the Fuel Cycle R\&D program. 
This page intentionally left blank 


\begin{abstract}
ORNL is developing advanced low-Cr oxide dispersion strengthened (ODS) FeCrAlY alloys for accident tolerant fuel cladding, and this report describes the fabrication and characterization of a new ODS FeCrAlYZr (CrAZY) tube. This CrAZY tube was produced by successive steps of pilgering and annealing, in collaboration with a Japanese tube manufacturer. Very fine, elongated sub-grain structure in the as-received tube was consistent with the fine sub-grain structure observed for CrAZY foils fabricated by cold rolling at ORNL and led to very high tensile strength at room temperature. The elongated grain structure along the pilgering direction resulted in lower ductility in the hoop direction compared to the ductility along the tube. Similar anisotropic tensile behavior was also observed for the CrAZY foil with very limited ductility perpendicular to the rolling direction. The foil and tube were heat treated in the 850$1100^{\circ} \mathrm{C}$ range to reduce the residual stress. Recrystallization was observed at temperature as low as $900^{\circ} \mathrm{C}$, with an increasing number of recrystallized grains with increasing temperature. Exposure for $1 \mathrm{~h}$ at $900^{\circ} \mathrm{C}$ resulted in a significant improvement of the foil and tube, with a moderate decrease of strength. Atom probe tomographic analysis revealed the presence of many nano oxide precipitates but also areas with fewer precipitates due to the relatively high extrusion temperature $\left(1100^{\circ} \mathrm{C}\right)$. Finally, the $\mathrm{CrAZY}$ tube showed good oxidation resistance in steam at temperature up to $1400^{\circ} \mathrm{C}$.
\end{abstract}

This report has been submitted as fulfillment of milestone M3FT-17OR020202081 titled, "Report on the Tensile Strength and Steam Oxidation Resistance of ODS FeCrAl Sheet and Tubes" for the Department of Energy Office of Nuclear Energy, Advanced Fuel Campaign of the Fuel Cycle R\&D program. 
This page intentionally left blank 


\section{INTRODUCTION}

\subsection{Backgrounds}

The Fukushima Daiichi accident led to new research programs in the United States (US) on materials for accident tolerant fuel (ATF) cladding [1,2]. One key parameter was the alloy high temperature steam oxidation resistance, and extensive work at Oak Ridge National Laboratory (ORNL) was carried out to develop low-Cr high-strength nuclear grade FeCrAlY alloys [3-9]. More than 200 feet of thin-walled seamless wrought FeCrAlY tubes were fabricated through ingot-metallurgy combined with thermomechanical treatments and a tube-drawing process [10], and some tubes were installed into the Hatch nuclear power plant (Baxley, GA) for in-service evaluation. In parallel, research was conducted on lowCr oxide dispersion strengthened (ODS) FeCrAlY alloys[11-17]. The mains goals were to maintain the high temperature steam oxidation resistance of wrought FeCrAl alloys, while improving the alloy strength and irradiation resistance due to the high number density of nano precipitates. Optimization of the alloy composition based on the microstructure, oxidation behavior and tensile properties led to the selection of an ODS Fe-10/12Cr-6Al-0.3Zr+0.3 $\mathrm{Y}_{2} \mathrm{O}_{3}$ alloy (named $\mathrm{CrAZY}$ ) [11-17]. Previous work on fabrication parameters also showed that the ball milling duration and extrusion temperature need to be optimized for a good balance between alloy strength and fabricability. As described in this report, all the data generated were used to fabricate a thin accident-tolerant ODS FeCrAl cladding.

\subsection{Master Rods Production}

A collaboration with Nippon Nuclear Fuel Development Co., Ltd. (NFD) and a Japanese tube producer was initiated to fabricate thin ODS tubes. The goal was to produce one long CrAZY tube by Pilgering [18], a compressive process that has been used in the past to fabricate both $\mathrm{FeCr}$ and FeCrAl ODS tubes [19-23]. As can be seen in Figure 1a, two master rods 20-22 $\mathrm{mm}$ in outside diameter (OD) and 250mm long, were, therefore, fabricated at ORNL and shipped to NFD. The rod compositions are given in Table 1. The only requirement in addition to the master rod dimensions from the tube producer was a hardness value lower than $350 \mathrm{HV}$ for the master rods, and rod extrusion was conducted at high temperature $\left(1100^{\circ} \mathrm{C}\right)$ to meet this criterion, with a final hardness of $\sim 300 \mathrm{HV}$ (Figure 1b). Details of the master rod production can be found elsewhere [16].

Table 1. Master rods composition measured by induction coupled plasma optical emission spectroscopy (most of the elements), combustion analysis (C and $\mathrm{S})$, and inert gas fusion analysis (O and $\mathrm{N})$

\begin{tabular}{|c|c|c|c|c|c|c|c|c|c|c|}
\hline \multirow[b]{2}{*}{ ID } & \multicolumn{10}{|c|}{ Composition, wt. $\%$} \\
\hline & $\begin{array}{c}\text { Extrusion } \\
\text { Temperature }\end{array}$ & $\mathrm{Fe}$ & $\mathrm{Cr}$ & $\mathrm{Al}$ & $\mathrm{Zr}$ & $\mathrm{Y}$ & $\mathrm{C}$ & $\mathrm{N}$ & $\mathrm{O}$ & $\mathrm{S}$ \\
\hline $10 \mathrm{Cr}-6 \mathrm{Al}-0.3 \mathrm{Zr}$ & Powder & 83.1 & 10 & 6.4 & 0.29 & & 40 & 20 & 190 & 30 \\
\hline CrAZY_1 & $1100^{\circ} \mathrm{C}$ & 83.46 & 9.71 & 6.03 & 0.27 & 0.22 & 690 & 171 & 1140 & 40 \\
\hline CrAZY_2 & $1100^{\circ} \mathrm{C}$ & 83.55 & 9.75 & 5.91 & 0.27 & 0.22 & 620 & 121 & 1130 & 30 \\
\hline
\end{tabular}



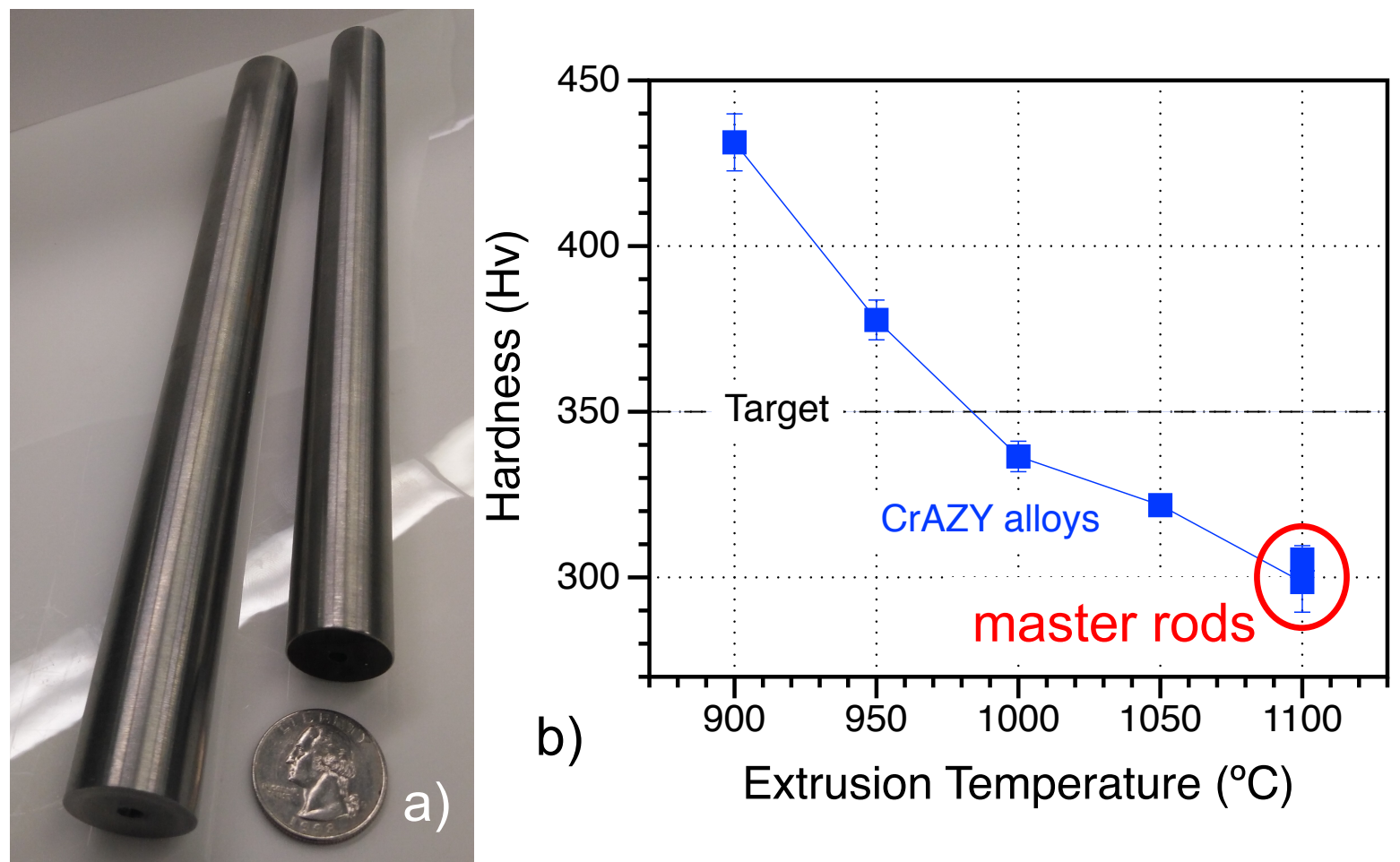

Figure 1: a) Extruded master rods, b) Evolution of the CrAZY alloy hardness with extrusion temperature

\subsection{Foil fabrication}

Plate samples $25 \mathrm{~mm}$ long and $3 \mathrm{~mm}$ thick were machined from one of the CrAZY master rods and then cold rolled to simulate the compressive pilgering process and assess the alloy deformability. $40 \%$ reduction was obtained at each cold rolling (CR) step, with a $\sim 10 \%$ reduction per pass. As can be seen in Figure $2 \mathrm{a}$, the foil thicknesses were $\sim 0.4 \mathrm{~mm}$ after 4 successive CR steps. Figure $2 \mathrm{~b}$ shows that the foil hardness measured on cross-section transverse to the rolling direction increased significantly after each CR step, to reach $420 \mathrm{HV}$ for the final $0.4 \mathrm{~mm}$ foils. From these results it was concluded that intermediate annealing steps would be required after each pilgering step to reduce tube hardness.
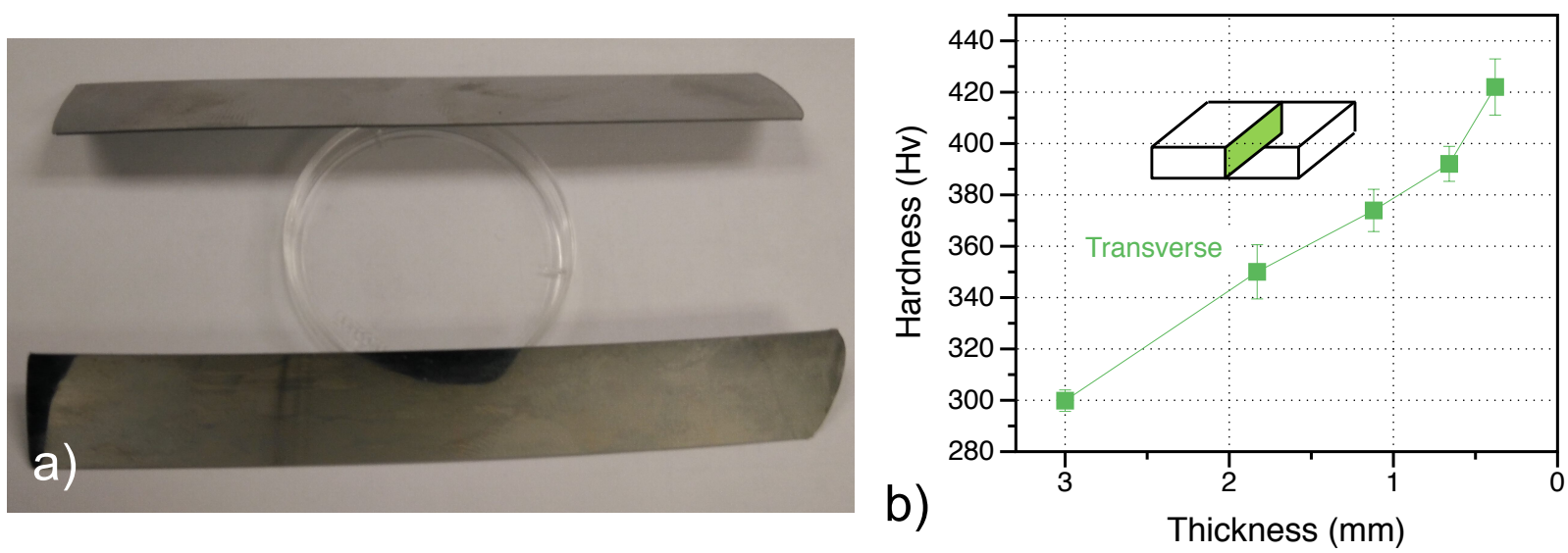

Figure 2: a) Cold rolled foils, b) Evolution of the CrAZY foil hardness with foil thickness 


\section{TUBE FABRICATION}

\subsection{Fabrication procedure}

The largest rod (22mm OD, CrAZY-1) was first gun drilled by the tube manufacturer to produce a $3 \mathrm{~mm}$ thick master tube. The tube was then pilgered four times, with a $\sim 0 \%$ thickness reduction at each pilgering step. Between each pilgering step the tube was annealed at high temperature under inert atmosphere to reduce the tube hardness and facilitate tube production. To determine the optimum annealing temperatures, pieces of the tube were cut by the tube manufacturer after each pilgering step and annealed at temperatures ranging from 850 to $1150^{\circ} \mathrm{C}$. Optical micrographs, such as the ones presented in Figure 3, and hardness measurements were used to determine the temperature high enough to release residual stresses but low enough to avoid coarse grain formation through grain recrystallization.
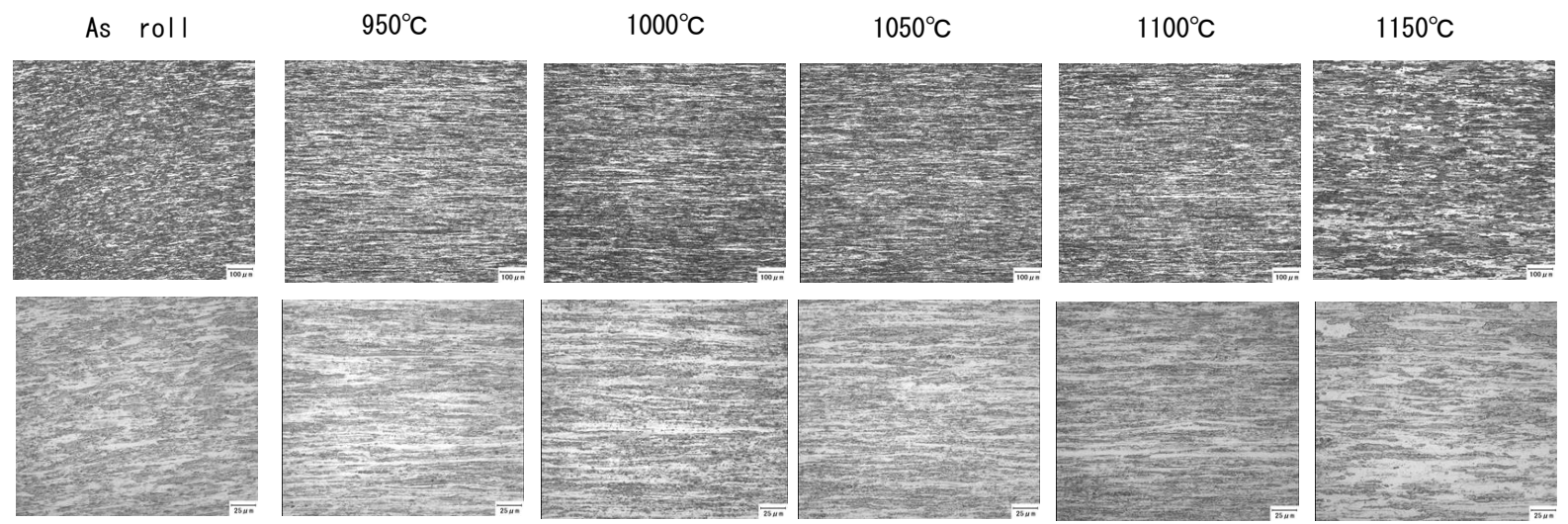

\section{Error! Reference source not found.}

Figure 3. Examples of optical micrographs taken by the tube manufacturer to determine the optimum annealing temperature after each pilgering step

\subsection{Tube production}

The evolution of the tube hardness after each pilgering and annealing step is compared in Figure 4 with the evolution of the foil hardness during cold rolling ( $40 \%$ reduction per CR step). The first anneal did not affect the tube hardness but the second and third anneals reduced significantly the tube hardness, leading to a final hardness of $350 \mathrm{HV}$, compared to $420 \mathrm{HV}$ for the $0.4 \mathrm{~mm}$ foils. Overview of the final tube is shown is Figure $4 \mathrm{~b}$, and the tube cross-section is displayed in Figure 5a. Image analysis was used to measure precisely the tube thickness, and the graphic in Figure $5 \mathrm{~b}$ highlights the good dimension tolerance of the tube, with an average OD of $8.47 \mathrm{~mm}$ and wall thickness varying from 491 to $501 \mu \mathrm{m}$. 

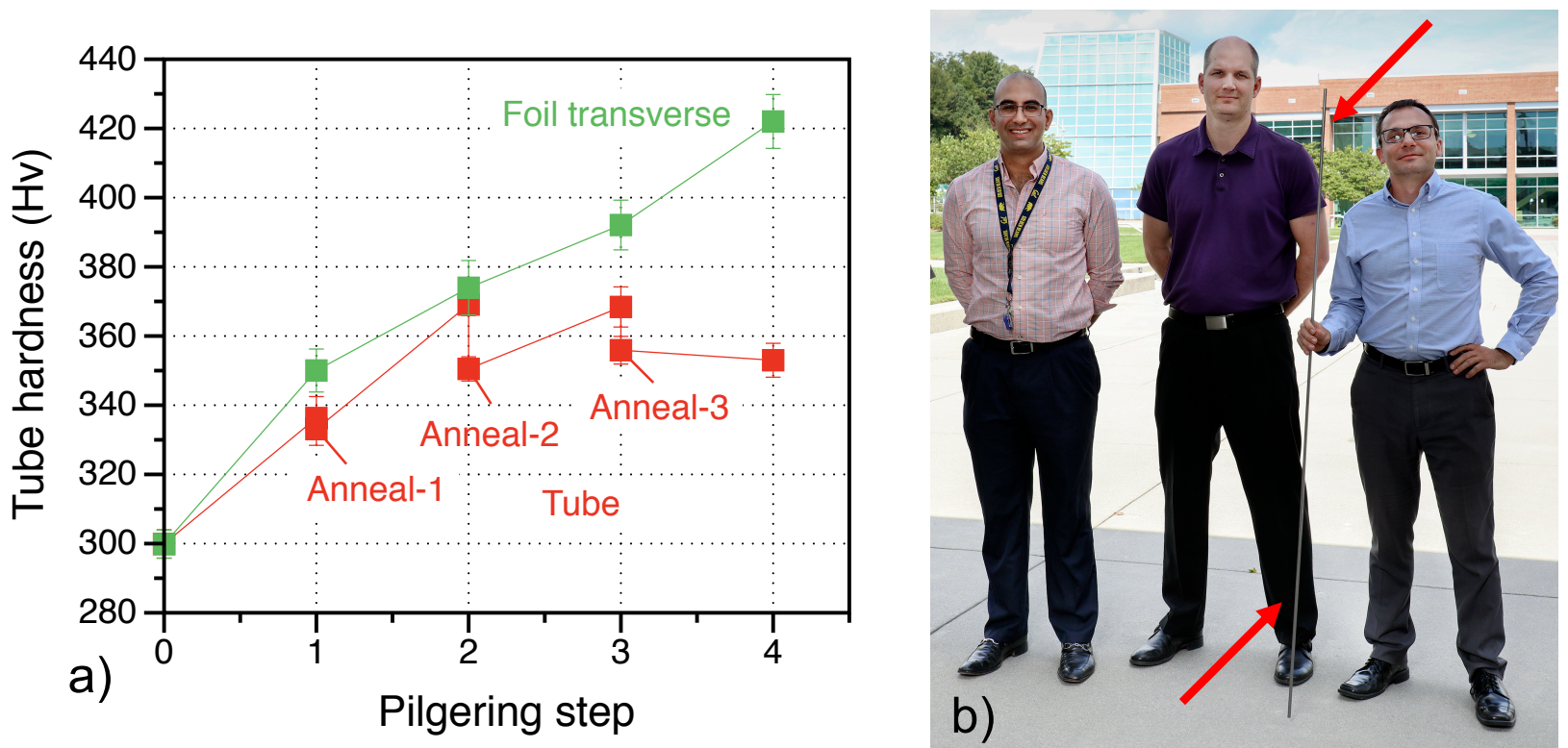

Figure 4. a) Evolution of the tube hardness after each pilgering and annealing step compared to the hardness evolution during cold rolling of the foil, b) Picture showing the resulting 66 inch long tube
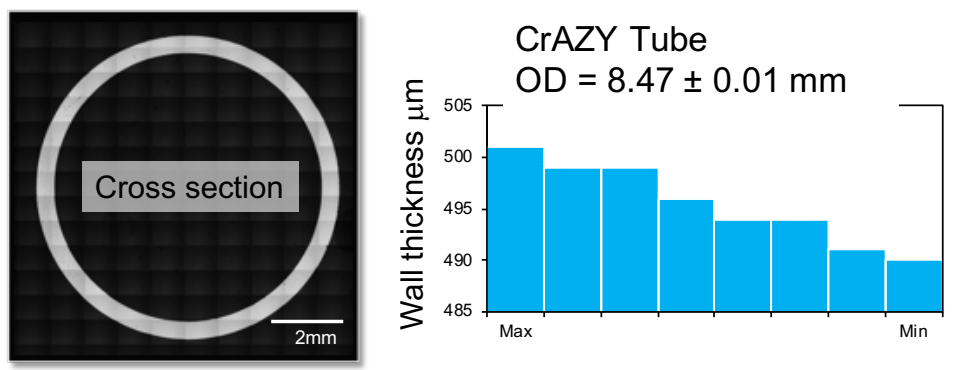

Figure 5. a) Tube cross-section, b) Wall thickness measurement 


\section{TUBE CHARACTERIZATION}

\subsection{Tube microstructure}

Cross-sectional back scattered scanning electron micrographs of the as-fabricated master rod, foil and tube are presented in Figure 6. Slightly elongated grains $\sim 1 \mu \mathrm{m}$ in size were observed for the as extruded master rod while very elongated nano sub-grains were observed for both the foil and the CrAZY tube. In the case of the tube the sub-grains were elongated along the pilgering direction, but for the foil the subgrains were elongated both along and perpendicular to the cold rolling direction. The significant cold rolling/pilgering deformation certainly resulted in the formation of dislocation networks and their subsequent rearrangement in sub-grains. Electron backscatter diffraction (EBSD) was used to further analyze the tube microstructure, and an EBSD orientation map generated along the pilgering direction is shown in Figure 7. The image to the left in Figure 7 identifies each grain as a separate color, with the image quality overlaid to allow for the subgrain texture to be better visualized. The corresponding image on the right is an inverse pole figure (IPF) map, where the colors indicate the crystallographic orientation of each grain with respect to the BCC crystal structure, parallel to the axis of pilgering as indicated by the white arrow. Most grains are oriented along the $<111>$ or $<100>$ directions, which is consistent with the alloy having a strong alpha-fiber $<110>$ texture in the pilgering direction. This map revealed the presence of many sub-grains inside elongated grains, up to $15 \mu \mathrm{m}$ in length. This subgrain texture is indicated by the shift in color across the large grains as one traces across the grain in the pilgering direction. Finally, atom probe tomography (APT) was performed to characterize the nano oxide precipitates present in the tube. The first map in Figure 8 highlights an area with many (Y,Al,O)-rich precipitates, less than $5 \mathrm{~nm}$ in size, but fewer precipitates were observed in the two other maps. This inhomogeneity is likely due to the high extrusion temperature required to decrease the master alloy hardness, $1100^{\circ} \mathrm{C}$, leading to the coarsening of some nano precipitates. 


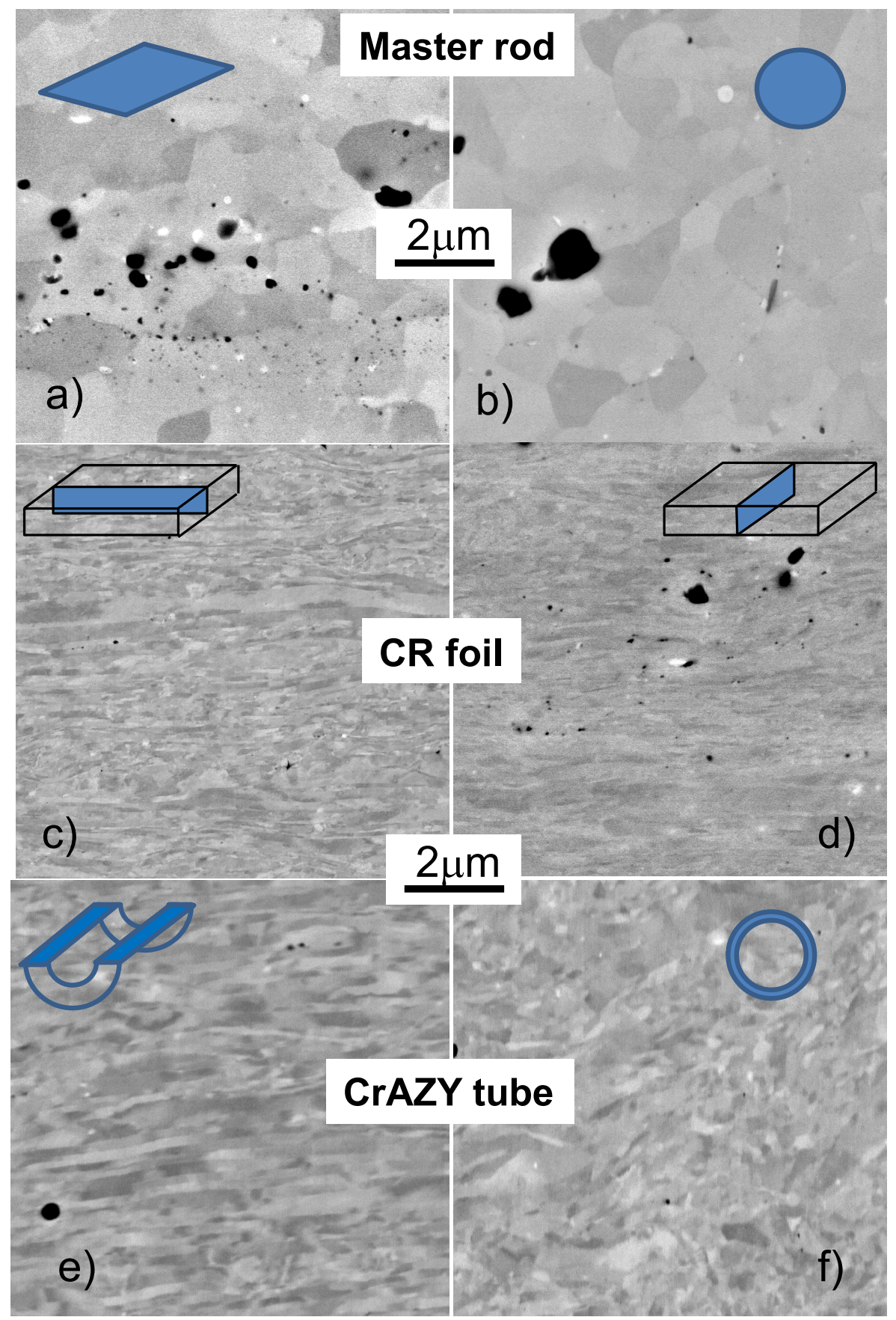

Figure 6. Cross-sectional back scattered scanning electron microscopy (BES-SEM) pictures of, a-b) the master rod, c-d) the cold rolled foil, and e-f) the tube. 


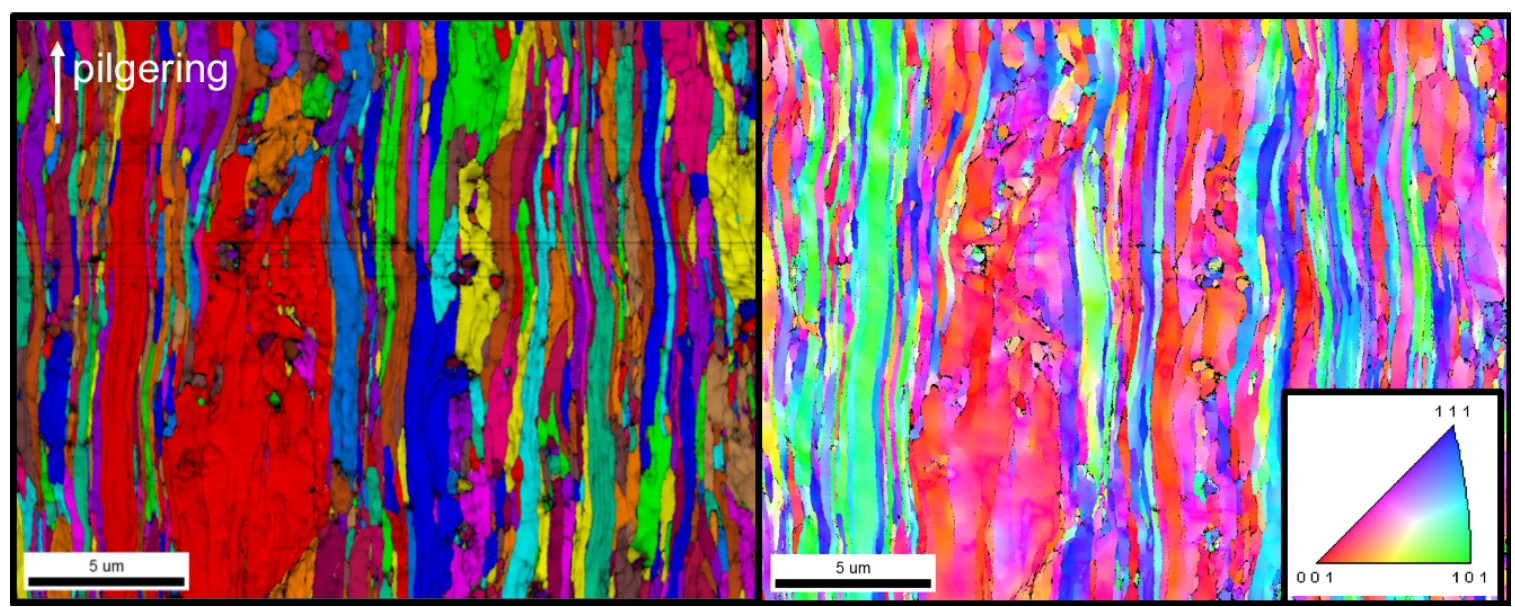

Figure 7. EBSD grain map (left) and corresponding pole figure map (right) of the tube along the pilgering direction
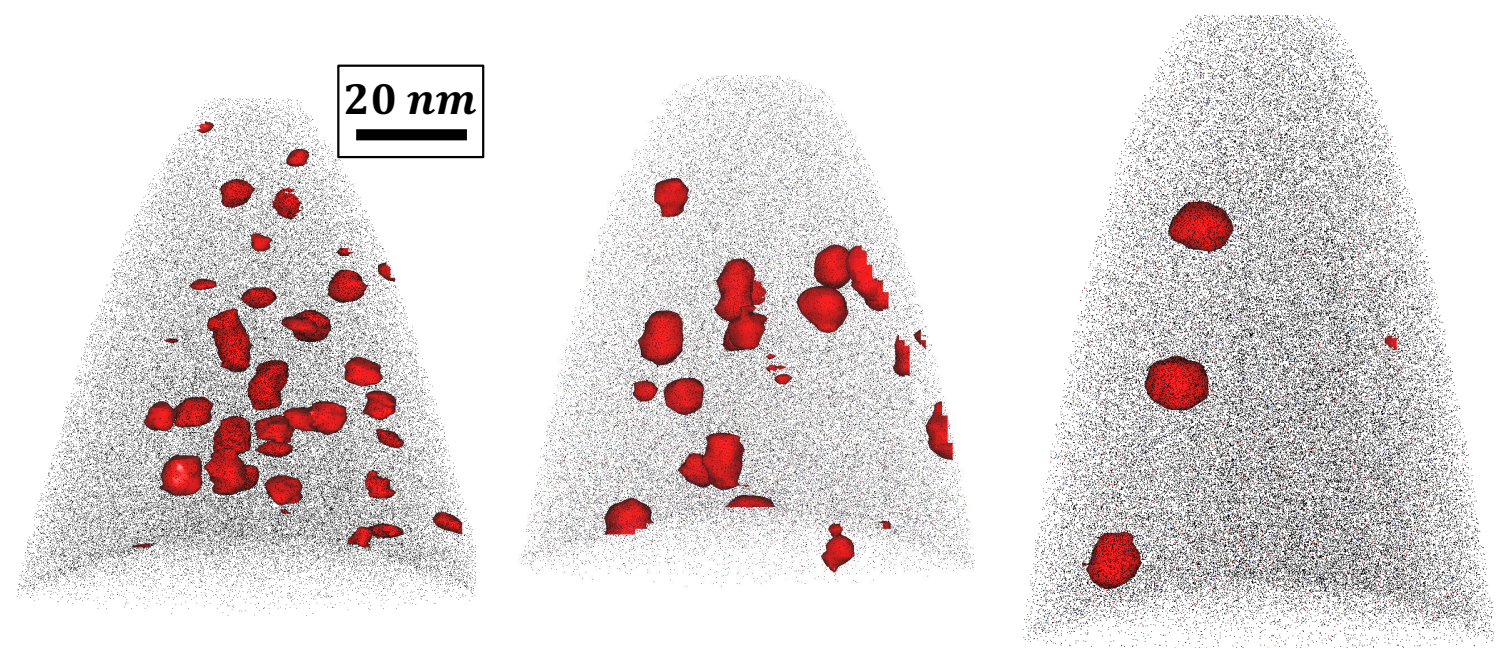

Figure 8. Three APT maps of the CrAZY tube showing the presence of $(\mathrm{Y}, \mathrm{Al}, \mathrm{O})$ nano precipitates

\subsection{Tube tensile properties}

SS-J3 sub-size tensile specimens were used to characterize the room temperature tensile properties of the master rod and the foil, both along and perpendicular the extrusion/cold rolling direction. For the CrAZY tube, specific ring and tube specimens were designed to measure the tube tensile properties along the tube length and in the hoop direction (Figure 9). 


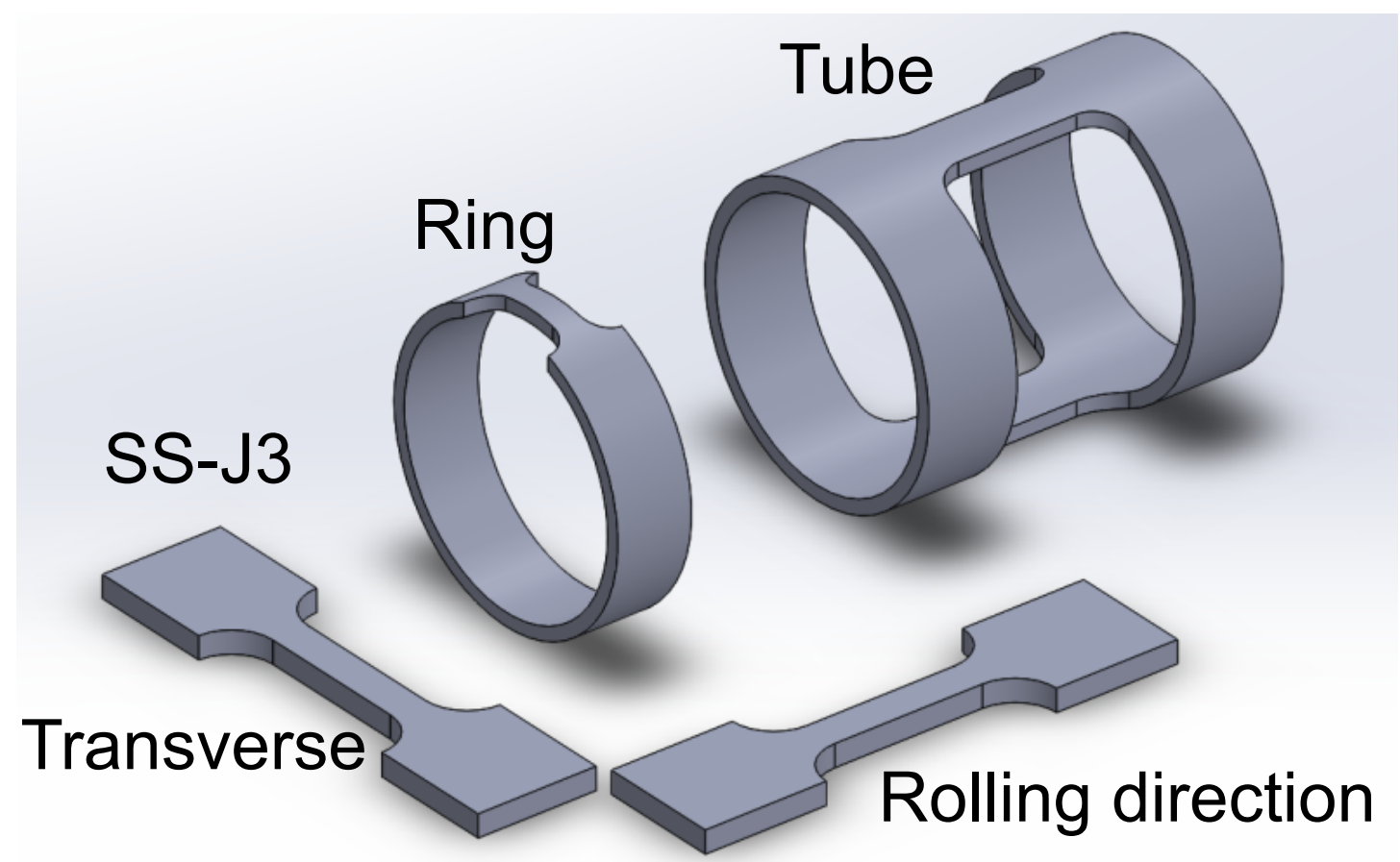

Figure 9. Schematic of the various specimens used to characterize the room temperature tensile properties of the master rod, foil and CrAZY tube.

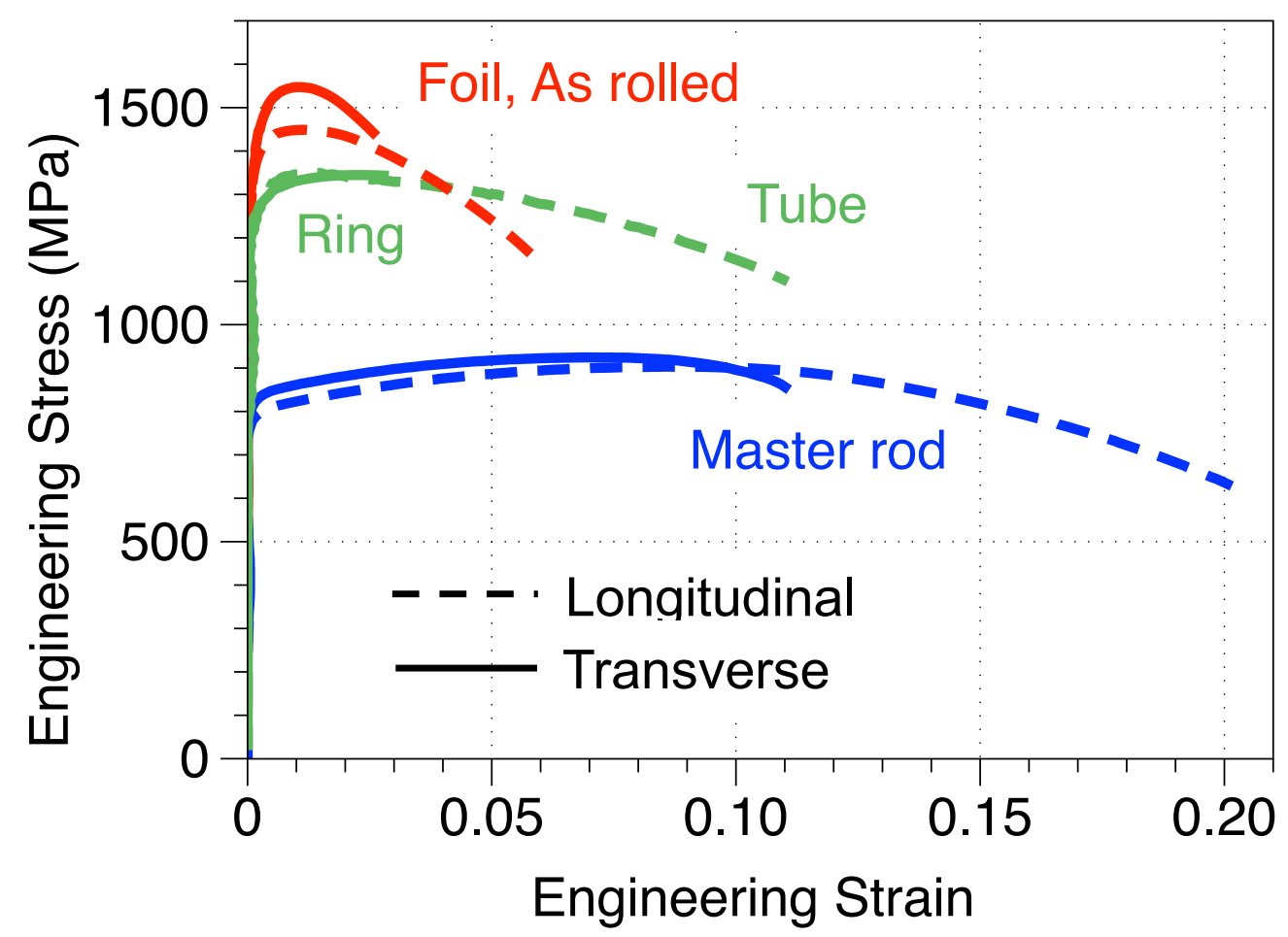

Figure 10. Tensile curves at room temperature of the master rod, foil and CrAZY tube 
The tensile properties of the master rod, foil and CrAZY tube are compared in Figure 10. Both the foil and the tube exhibited significantly higher yield strength (YS) and ultimate tensile strength (UTS) compared to the as extruded rod, but lower ductility. This difference is attributed to the loss of work hardening capacity for the alloy after significant deformation induced dislocation accumulation and subgrain formation during each subsequent pilgering step, resulting in an immediate transition to plastic instability after yielding. For all the materials the YS and UTS were quite isotropic, but ductility was significantly lower for the master rod and foil perpendicular to the extrusion or rolling direction, respectively. Ductility was also much lower for the tube in the hoop direction (ring specimen). All these results are, again, consistent with the anisotropic microstructure with very elongated grains and subgrains.

\subsection{Steam oxidation testing}

As can be seen in Figure 11a, a specific set up was designed to conduct high temperature oxidation testing in steam on tube specimens. To simulate different accident scenarios, various heating schedules were used to test wrought $\mathrm{FeCrAl}$ tube [25], and the ramp chosen for the CrAZY tube was as follows: heating from 20 to $600^{\circ} \mathrm{C}$ in $\mathrm{Ar}$ at $20^{\circ} \mathrm{C} / \mathrm{min}$ followed by heating in steam from $600^{\circ} \mathrm{C}$ to $1400^{\circ} \mathrm{C}$ or $1450^{\circ} \mathrm{C}$, with a final $1 \mathrm{~min}$ hold. BSE-SEM pictures of the oxide scale after the $1400^{\circ} \mathrm{C}$ test is shown in Figure $11 \mathrm{~b}$ and $11 \mathrm{c}$. On the OD side, a $\sim 5 \mu \mathrm{m}$ thick alumina scale formed, while on the inside diameter (ID) side Fe-rich oxides were also observed. The tube coupon tested at $1450^{\circ} \mathrm{C}$ was completely oxidized after $1 \mathrm{~min}$. These results are consistent with steam oxidation tests conducted on various ODS Fe-12Cr-5Al alloys at $1400^{\circ} \mathrm{C}$ and $1450^{\circ} \mathrm{C}$ [17], with thin oxide scale after $4 \mathrm{~h}$ at $1400^{\circ} \mathrm{C}$ but coupons completely oxidized after $4 \mathrm{~h}$ at $1450^{\circ} \mathrm{C}$.
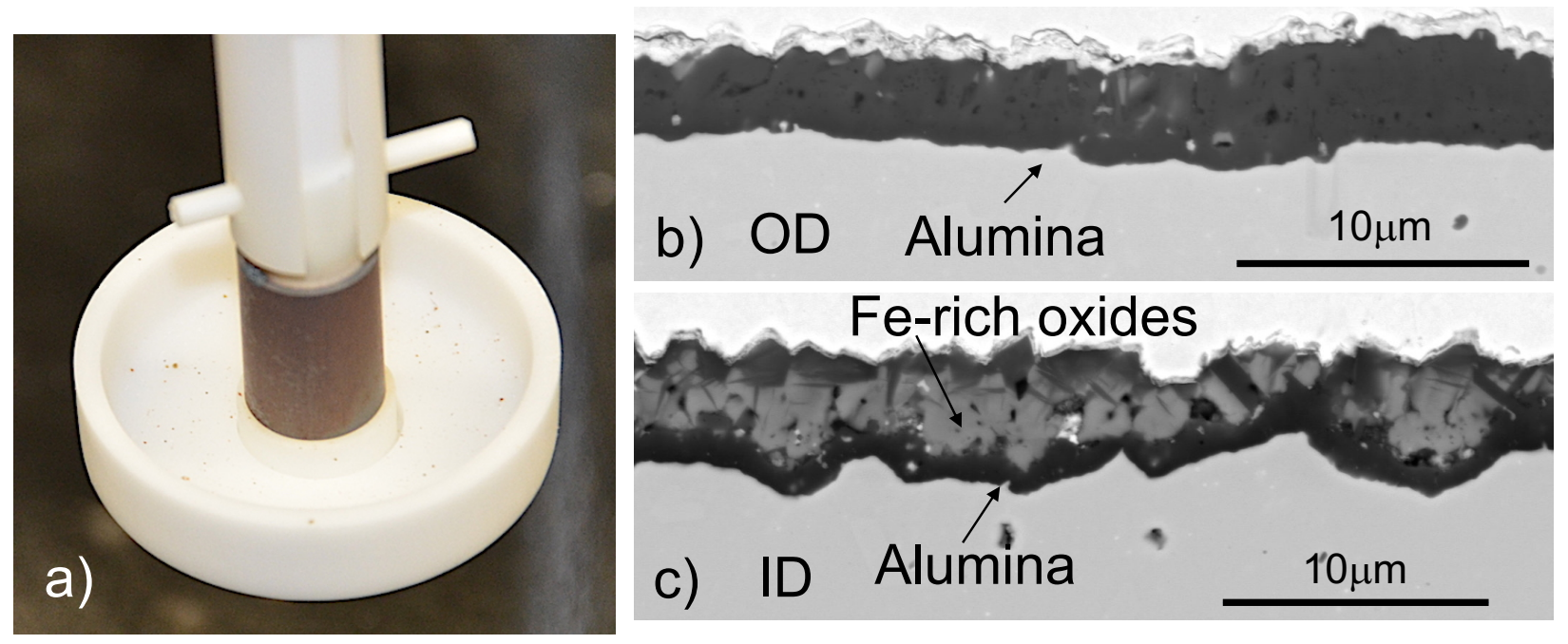

Figure 11. Steam oxidation testing, a) experimental set up with CrAZY tube coupon ramped up to $1400^{\circ} \mathrm{C}, \mathrm{b}$ ) and c) oxide scale grown on the CrAZY tube after the $1400^{\circ} \mathrm{C}$ test

\section{TUBE ANNEALING}

\subsection{Microstructure evolution}

The limited hoop ductility of the CrAZY tube could potentially be an issue during operation and annealing trials were conducted at $900^{\circ} \mathrm{C}-1100^{\circ} \mathrm{C}$ on both the foil and the CrAZY tube to release some of the residual stress. As can be seen in Figure 12a and 12b, local grain recrystallization was observed for both the foil and the tube after $1 \mathrm{~h}$ at $900^{\circ} \mathrm{C}$, with also the formation of small voids. Grain recrystallization 
increased with increasing the annealing temperature, and Figure $12 \mathrm{c}$ and $12 \mathrm{~d}$ show that a significant portion of the foil and tube was recrystallized after exposure at $1100^{\circ} \mathrm{C}$ for $1 \mathrm{~h}$.

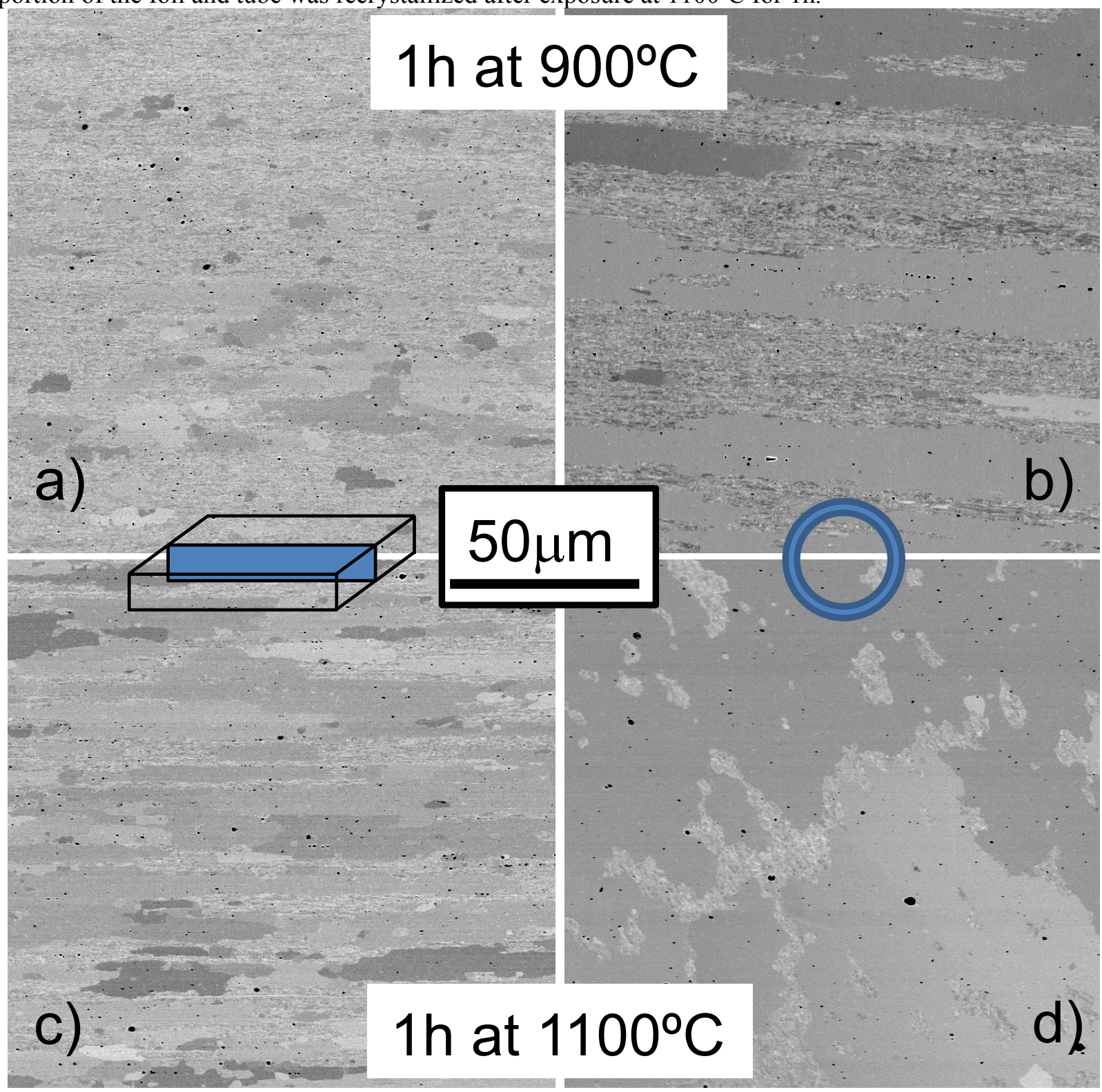

Figure 12. BSE-SEM micrographs of annealed materials, a) foil, $900^{\circ} \mathrm{C}, \mathrm{b}$ ) $\mathrm{CrAZY}$ tube, $900^{\circ} \mathrm{C}$, c) foil, $1100^{\circ} \mathrm{C}$, d) $\mathrm{CrAZY}$ tube, $1100^{\circ} \mathrm{C}$

\subsection{Mechanical testing}

SS-J3 specimens machined from the foil along and perpendicular the build direction as well as ring and tube specimens were encapsulated in an ampoule quartz filled with $\mathrm{Ar}+4 \% \mathrm{H}$ and then annealed at $900^{\circ} \mathrm{C}$ for $1 \mathrm{~h}$. The resulting tensile curves at room temperature are compared in Figure 13 with the tensile properties of the as fabricated materials. As expected, a significant increase in ductility but decrease in strength was observed for both the foil and tube after annealing for $1 \mathrm{~h}$ at $900^{\circ} \mathrm{C}$. 


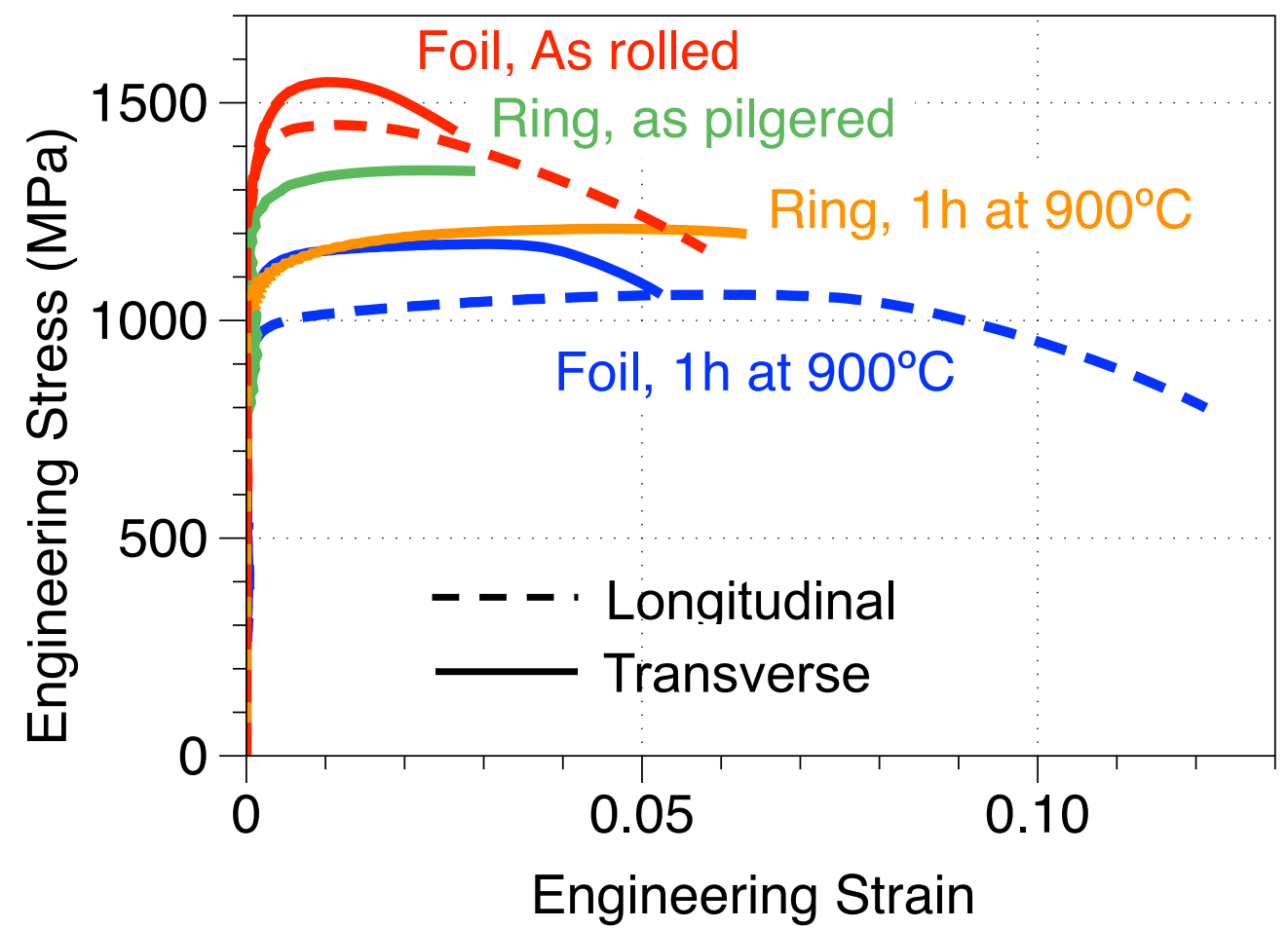

Figure 13. Curves comparing the tensile behavior of the foil and CrAZY tube before and after exposure for $1 \mathrm{~h}$ at $900^{\circ} \mathrm{C}$

\section{SUMMARY AND FUTURE WORK}

A new ODS FeCrAlYZr "CrAZY" tube was fabricated by pilgering in collaboration with a Japanese tube manufacturer. Very fine sub-grain structure due to the extreme compressive stress during pilgering led to very high longitudinal and hoop strengths at room temperature. The grains and fine sub-grains were elongated along the pilgering direction, which led to anisotropic tensile properties with the ductility in the hoop direction being lower than along the tube. Post annealing treatment to reduce the tube residual stress was found to be a possible route to improve the tube ductility with a moderate reduction of the tube strength. All these results were consistent with previous experiments conducted on cold rolled foils. The CrAZY tube showed also good oxidation resistance in steam up to $1400^{\circ} \mathrm{C}$, and specimens have been machined to evaluate the irradiation resistance of the tube at the high flux isotope reactor (HFIR). On-going work aims at the fabrication of at least 5 new CrAZY tubes through a similar collaboration with an industrial partner. Slight modifications of the process parameters and alloy chemistry are expected to lead to further improvement of the tubes microstructure and properties. 


\section{REFERENCES}

[1] S.J. Zinkle, K.A. Terrani, J.C. Gehin, L.J. Ott, L.L. Snead, Journal of Nuclear Materials, 448, 374379 (2014).

[2] K. A. Terrani, S. J. Zinkle, L. L. Snead, Journal of Nuclear Materials, 448, 420-435 (2014).

[3] B. A. Pint, K. A. Unocic and K. A. Terrani, Materials at High Temperatures, 32, 28-35 (2015).

[4] B. A. Pint, K. A. Terrani, Y. Yamamoto and L. L. Snead, Metallurgical and Materials Transactions E, 190-196 (2015).

[5] Y. Yamamoto, B.A. Pint, K.A. Terrani, K.G. Field, L.L. Snead, M3FT-13OR0202291, ORNL/LTR2013/322, Oak Ridge National Laboratory (2013).

[6] Y. Yamamoto, B.A. Pint, K.A. Terrani, K.G. Field, Y. Yang, and L.L. Snead, Journal of Nuclear Materials, 467, 703716 (2015).

[7] K. G. Field, X. Hu, K. C. Littrell, Y. Yamamoto, L. L. Snead, Journal of Nuclear Materials, 465, 746755 (2015).

[8] S. A. Briggs, P. D. Edmondson, K. C. Littrell, Y. Yamamoto, R. H. Howard, C. R. Daily, K.A.

Terrani, K. Sridharan, K. G. Field, Acta Materialia, 129, 217-228 (2017).

[9] N.M. George, K.A. Terrani, J.J. Powers, ORNL report TM-2013/121 (2013).

[10] Y. Yamamoto and Z. Sun, ORNL report, ORNL/TM-2017/338 (2017).

[11] B. A. Pint, S. Dryepondt, K. A. Unocic and D. T. Hoelzer, JOM 66, 2458-2466 (2014).

[12] K.A. Unocic, D. T. Hoelzer and B. A. Pint, Materials at High Temperatures, 32, 123-132 (2015).

[13] S. Dryepondt, K. A. Unocic, D. T. Hoelzer, B. A. Pint, ORNL report, ORNL/TM-2014/380 (2015).

[14] K. A. Unocic, B. A. Pint, and D. T. Hoelzer, Journal of Materials Science, 51, 9190-9206 (2016).

[15] S. Dryepondt, C. Massey, P. D. Edmonson, ORNL report, ORNL/TM-2016/456 (2016).

[16] S. Dryepondt, C. Massey, Maxim N. Gussev, ORNL report, ORNL/TM-2017/445 (2017).

[17] S. Dryepondt, K.A. Unocic, D.T. Hoelzer, C.P. Massey and B.A. Pint, Journal of Nuclear Materials, 501, 59-71 (2018).

[18] Cold Pilger Rolling: Part One, in the website of Total Materia, Apr. 2013: http://www.totalmateria.com/page.aspx?ID=CheckArticle\&site $=k t s \& N M=396$

[19] S. Ukai, M. Harada, H. Okada, M. Inoue, S. Nomura, S. Shikakura, T. Nishida, M. Fujiwara and K. Asabe, Journal of Nuclear Materials, 204, 74-80 (1993).

[20] S. Ukai, T. Nishida, H. Okada, T. Okuda, M. Fujiwara, K. Asabe, Journal of Nuclear Science and Technology. 34, 256-263 (1997).

[21] S. Ukai, M. Fujiwara, Journal of Nuclear Materials, 307-311, 749-757 (2002).

[22] S. Ukai, T. Narita, A. Alamo, P. Parmentier, Journal of Nuclear Materials, 329-333, 356-361 (2004).

[23] L. Toualbi, C. Cayron, P. Olier, R. Logé, Y. de Carlan, Journal of Nuclear Materials, 442, 410-416 (2013).

[24] S. Ukai, N. Oono, K. Sakamoto, T. Torimaru, T. Kaito, A. Kimura, S. Hayashi, Proceedings of TopFuel 2016, Boise, Idaho, September 11-16, 2016, p. 681-689, ANS (2016).

[25] B.A. Pint, Corrosion Reviews, 35, 167-175 (2017). 